\title{
The effect of yellow mealworm larvae meal supplementation in broiler diets on meat quality
}

\author{
Ondřej Št’astník ${ }^{1}$, Jakub Novotný ${ }^{1}$, Andrea Roztočilová1, Miroslav Jůzl ${ }^{2}$, \\ Markéta Piechowiczová ${ }^{2}$, Petr Kouřil ${ }^{3}$, Silvie Satrapová ${ }^{4}$, Lubor Lacina ${ }^{4}$, Libor Kalhotka ${ }^{3}$, \\ Leoš Pavlata ${ }^{1}$, Eva Mrkvicová ${ }^{1}$ \\ ${ }^{1}$ Mendel University in Brno, Faculty of AgriSciences, Department of Animal Nutrition and Forage Production, \\ Brno, Czech Republic \\ ${ }^{2}$ Mendel University in Brno, Faculty of AgriSciences, Department of Food Technology, Brno, Czech Republic \\ ${ }^{3}$ Mendel University in Brno, Faculty of AgriSciences, Department of Agrochemistry, Soil Science, \\ Microbiology and Plant Nutrition, Brno, Czech Republic \\ ${ }^{4}$ Underground Food s.r.o, Brno, Czech Republic \\ Received November 16, 2020 \\ Accepted August 31, 2021
}

\begin{abstract}
The aim of this study was to evaluate the effect of Tenebrio molitor larvae meal supplementation in chicken diets on the chemical composition and sensory quality of meat. The experiment was conducted on 120 Ross 308 male broilers from day 12 to day 38 of their age. Broilers were divided into three equal groups with 5 replicates per treatment. The two experimental groups received feed mixtures containing 2\% (TM2; $\mathrm{n}=40)$ and $5 \%(\mathrm{TM} 5 ; \mathrm{n}=40)$, respectively of yellow mealworm (Tenebrio molitor L.) meal. The third group (TM0; $\mathrm{n}=40$ ) was control, receiving $0 \%$ of mealworms in diet. The addition of mealworm meal to diets in this trial do not worsen the chemical composition or sensory characteristics of the thigh meat of broilers. The control chickens had a higher live weight $(P<0.05)$ compared to the experimental groups at the end of the trial. The lowest live weight and feed intake was determined in group TM2 $(P<0.05)$. The highest feed intake $(P<0.05)$ was found in the control group. The breast meat from the control group was rated better $(P<0.05)$ in flavour compared to the groups receiving $2 \%$ and $5 \%$ of yellow mealworms. The primary requirement for the use of any ingredient in feed is that it does not adversely affect food safety and quality. In our study, the inclusion of $2 \%$ and $5 \%$ mealworm meal in the broiler's diet had no influence on meat quality.
\end{abstract}

Tenebrio molitor, insect, poultry nutrition, sensory acceptability

By 2050, a 60-70\% increase in the consumption of animal products is expected (Makkar et al. 2014), correlating with the human population which is estimated to increase to 9 billion people. This increase in food consumption will require additional resources and animal feed will be the most demanding in terms of limited availability of natural resources, continued climate change, and food-feed-fuel competition (Makkar et al. 2014). The growing global need to find alternative and sustainable protein sources warrants research in the field of unconventional foodstuffs such as insects (Gasco et al. 2020).

Insect farming may be one of the ways to enhance food and feed sufficiency (van Huis 2013). Insects grow and reproduce easily; being cold-blooded, they have high feed conversion efficiency. On average, $1 \mathrm{~kg}$ of insect biomass can be produced from $2 \mathrm{~kg}$ of feed biomass (Collavo et al. 2005). According to the Commission Regulation (EC) $1069 / 2009$, insect farming is considered as livestock farming. So, the insects must be fed in the same way as livestock animals. Mealworms are produced industrially as feed for pet and zoo animals, including birds, reptiles, small mammals, amphibians, and fish (Makkar et al. 2014). Larval and pupal stages are rich in crude fat. The crude fat content is approximately $31-43 \%$ on the dry matter (DM) basis (Ghaly and Alkoaik 2009; Makkar et al. 2014). 
Tenebrio molitor L. (TM) larvae (mealworms) are easy to breed and feed, and they have a valuable protein profile. The crude protein content is approximately 46-60\% DM (Ghaly and Alkoaik 2009; Makkar et al. 2014). The protein quality of mealworms is similar to that of soybean-extracted meal. The content of methionine in mealworms depends on the substrate and ranges from $0.48 \%$ to $1.80 \%$ of crude protein. Generally, the nutrient and amino acid content differs depending on the larval size, weight, and substrate. Insects offer many benefits in the nutritional value and the amino acid composition of their proteins, and generally meet animal requirements for good health, growth (Gasco et al. 2020), and production. Regarding the sensory properties of mealworms, the flavour has been described as nutty with a taste of umami and cereals in a study by Wendin et al. (2019). It can be assumed that the nutty taste of mealworms passes through the feed into meat, possibly affecting its odour and taste. In terms of the meat quality of broilers fed mealworms, few studies are presently available.

The aim of this study was to evaluate the effect of Tenebrio molitor larvae meal supplementation in broiler's diets (replacing a proportion of soybean meal) on the chemical composition and sensory characteristics of breast and thigh muscles.

\section{Materials and Methods}

The experimental procedures were reviewed and approved by the Animal Care Committee of Mendel University in Brno and by the Ministry of Education, Youth and Sports (MSMT- 22771/2019-3).

\section{Animals and diets}

The yellow mealworm meal used in our experiment was obtained from Underground Food s.r.o. (Brno, Czech Republic). The experiment was conducted on 120 Ross 308 male chickens. The broilers were fed a starter feed mixture until 10 days of age. The time from day 11 to day 12 of age was a preparatory period. The chickens were fed experimental and control grower feed mixtures until the end of the experiment. The trial was performed from day 12 to day 38 of the broilers' age. Their live weight was measured every week during the trial. The broilers were divided by body mass into three equal groups with 5 replicates per treatment, i.e. there were eight animals per replicate pen. The two experimental groups received feed mixtures containing $2 \%(\mathrm{TM} 2 ; \mathrm{n}=40)$ and $5 \%$ (TM5; $\mathrm{n}=40$ ) of yellow mealworm (Tenebrio molitor L.) meal. The third group (TM0; $\mathrm{n}=40$ ) was the control group, receiving $0 \%$ of mealworm meal in diet. The mealworm meal was mixed with the other components into a homogeneous feed mixture. Mealworm meal replaced the appropriate proportion of soybean extracted meal. Table 1 shows the composition of experimental diets. Table 2 shows proximate analyses of used yellow mealworm meal and diets. The rations were calculated according to the Broiler Nutrition Specifications (Aviagen Group 2019) as isonitrogenous and isoenergic. The diet was offered to broilers in the mash form. The chickens had free access to feed and water. The chemical composition of the nutrient content of diets was determined for dry matter, crude protein, ether extract, crude fibre and ash according to the Commission Regulation (EC) $152 / 2009$. The conventional deep litter system with wood shavings was used, with a density of $24 \mathrm{~kg} / \mathrm{m}^{2}$. Room temperature, humidity, and lighting regime were controlled according to the requirements for the given age of chickens (Aviagen Group 2018).

\section{Meat samples preparation}

At the end of the experiment, six birds were randomly selected from each group, weighed, and slaughtered. Carcass yield was calculated. Breast and leg meats without skin were separated from carcasses after chilling. All visible external fat was removed from sample meats. The breast and leg meat were weighed, and their percentage of carcass weight was calculated. The left part of the breast and the left thigh were packed up in aluminium foil, marked, and stored a $\mathrm{t}-20^{\circ} \mathrm{C}$ until sensory analyses. Meat from the right half of breast and the deboned right thigh was milled (Moulinex Moulinette; France). The dry matter content of meat was determined by a method using sea sand and total nitrogen according to Kjeldahl using OPSIS Liquid Line (KjelROC Analyser; KD 310-A-1015; Sweden). The total fat content was determined gravimetrically after extraction with diethyl ether under reflux for $6 \mathrm{~h}$.

\section{Sensory analysis}

Sensory analysis of breast $(n=6)$ and thigh meat $(n=6)$ samples (for each treatment) were evaluated by 10 panellists in a specialized sensory laboratory (Department of Food Technology, Mendel University in Brno) according to ISO 8589. Each sample (breast and thigh) was separately heat-treated in a convection oven (Rational SSC WE61, Germany) under defined conditions $\left(200{ }^{\circ} \mathrm{C}, 60 \%\right.$ humidity, one hour). The professional evaluation group was represented by a panel of trained panellists under defined terms (ISO 8586). It used a graphic non-structured scale $(100 \mathrm{~mm} ; 0=$ the worst, $100=$ the best; Hoffman et al. 2020) to compare the descriptors (odour, colour, fibriness, chewiness, juiciness, flavour, fatty taste) of the experimental group with the control group. 
Table 1. Nutrient composition of diets $(\mathrm{g} / \mathrm{kg})$.

\begin{tabular}{lrrr}
\hline Component & TM0 & TM2 & TM5 \\
\hline Soybean meal & 335.4 & 311.6 & 275.4 \\
Wheat & 287.0 & 289.0 & 291.4 \\
Maize & 271.4 & 277.9 & 289.9 \\
Rapessed oil & 50.0 & 45.5 & 37.6 \\
Premix* & 30.0 & 30.0 & 30.0 \\
Yellow mealworm & 0.0 & 20.0 & 50.0 \\
L-lysine & 8.1 & 8.1 & 8.1 \\
Monocalcium phosphate & 7.2 & 6.6 & 5.9 \\
L-threonine & 5.0 & 5.0 & 5.0 \\
DL-methionine & 3.6 & 3.5 & 3.5 \\
CaCO & 2.4 & 2.8 & 3.2 \\
\hline
\end{tabular}

*Premix composition (per kg): lysine $70 \mathrm{~g}$; methionine $75 \mathrm{~g}$; threonine $31 \mathrm{~g}$; calcium $190 \mathrm{~g}$; phosphorus $33 \mathrm{~g}$; sodium $46 \mathrm{~g}$; copper $500 \mathrm{mg}$; iron 2,500 mg; zinc 3,300 mg; manganese 3,300 mg; iodine $34.20 \mathrm{mg}$; selenium $12 \mathrm{mg}$; tocopherol 1,500 mg; calciferol 165,000 international units (IU); phylloquinone $44 \mathrm{mg}$; thiamine $135 \mathrm{mg}$; riboflavin $280 \mathrm{mg}$; pyridoxine $200 \mathrm{mg}$; cobalamin $960 \mathrm{mg}$; biotin $6 \mathrm{mg}$; niacinamid 1,200 mg; folic acid $55 \mathrm{mg}$, calcium pantothenate $445 \mathrm{mg}$; choline chloride 6,000 mg; butylhydroxyanisol $41 \mathrm{mg}$; butylhydroxytoluen $182 \mathrm{mg}$. TM0 - 0\% mealworms; TM2 - 2\% mealworms; TM5 - 5\% mealworms.

Table 2. The mean chemical analyses of the used mealworm meal and experimental diets (in dry matter).

\begin{tabular}{lccrr}
\hline & Mealworm meal & TM0 & TM2 & TM5 \\
\hline AME $_{\mathrm{N}}(\mathrm{MJ} / \mathrm{kg})$ & - & 12.65 & 12.66 & 12.65 \\
Crude protein (\%) & 53.25 & 20.89 & 20.71 & 21.61 \\
SID Lysine (\%) & - & 1.16 & 1.16 & 1.16 \\
SID Methionine (\%) & - & 0.50 & 0.49 & 0.49 \\
SID Met+Cys (\%) & - & 0.87 & 0.87 & 0.87 \\
SID Threonine (\%) & - & 0.78 & 0.78 & 0.78 \\
Ether extract (\%) & 29.35 & 6.48 & 6.50 & 6.72 \\
Crude fibre (\%) & 6.21 & 2.77 & 3.12 & 2.80 \\
Ash (\%) & 3.90 & 6.23 & 5.63 & 5.61 \\
\hline
\end{tabular}

$\mathrm{AME}_{\mathrm{N}}$ - apparent metabolisable energy (Voght 1984); SID - standardised ileal digestibility.

TM0 $-0 \%$ mealworms; TM $2-2 \%$ mealworms; TM $5-5 \%$ mealworms.

\section{Statistical analysis}

The data were processed by Microsoft Excel (USA) and StatSoft Statistica version 12.0 (USA). Shapiro-Wilk $\mathrm{W}$ test was used to test the normality of data distribution. The data set was well-modelled by normal distribution. One-way analysis of variance (ANOVA) was used to determine the differences between groups. To ensure evidential differences, Scheffé's test was applied and $P<0.05$ was regarded as a significant difference.

\section{Results}

Live weight, carcass yield and meat chemical composition of broilers

The mealworms used had $53.25 \%$ crude protein and $29.35 \%$ ether extract in DM (Table 2). The initial body weight of broilers was equal at the start of the experiment (day 12 of age). The broilers' final live weight was higher $(P<0.05)$ in the control group compared to experimental group TM5 (Table 3). The lowest live weight and feed intake was achieved in group TM2. The highest feed intake was found in the control group. These results were significant $(P<0.05)$. In our experiment, one, four, and three deaths occurred in the control, TM2, and TM5 groups, respectively. 
The mean carcass yield and breast and thigh meat yield are shown in Table 4. There were no significant differences $(P>0.05)$ among all three groups of broiler chickens. The chemical composition of the chicken's meat was not different as well.

\section{Sensory analysis of meat}

The sensory evaluation of breast meat revealed a significant difference $(P<0.05)$ in the flavour descriptor for the control group compared to groups TM2 and TM5 (Table 5). The panellists did not find any differences in sensory analysis of the thigh meat of the broilers (Table 6).

Table 3. The initial body weight and live weight of broilers at 38 days of age and the mean feed intake and feed conversion ratio per trial (mean \pm standard error).

\begin{tabular}{lcccccc}
\hline Group & $\mathrm{n}$ & $\begin{array}{c}\text { Initial body } \\
\text { weight }(\mathrm{g})\end{array}$ & $\mathrm{n}$ & $\begin{array}{c}\text { Final body } \\
\text { weight }(\mathrm{g})\end{array}$ & Feed intake $(\mathrm{g})$ & $\begin{array}{c}\text { Feed conversion } \\
\text { ratio }\end{array}$ \\
\hline TM0 & 40 & $270 \pm 4.08$ & 39 & $2,426 \pm 62.72^{\mathrm{b}}$ & $3,455 \pm 73.31^{\mathrm{b}}$ & $1.43 \pm 0.03$ \\
TM2 & 40 & $270 \pm 2.44$ & 36 & $2,126 \pm 104.81^{\mathrm{a}}$ & $3,045 \pm 91.97^{\mathrm{a}}$ & $1.43 \pm 0.04$ \\
TM5 & 40 & $265 \pm 2.80$ & 37 & $2,257 \pm 72.33^{\mathrm{ab}}$ & $3,204 \pm 72.03^{\mathrm{ab}}$ & $1.44 \pm 0.06$ \\
\hline
\end{tabular}

a:b - different superscripts in one column mean significant differences $(P<0.05)$. TM0 $-0 \%$ mealworms; TM2 $-2 \%$ mealworms; TM5 $-5 \%$ mealworms. Feed conversion ratio $\mathrm{n}=5$.

Table 4. Body composition (\%) and chemical analysis of breast and thigh meat (\%) of broiler chickens (mean \pm standard error).

\begin{tabular}{llrrr}
\hline Group & & TM0 & TM2 & TM5 \\
\hline n & & 6 & 6 & 6 \\
\hline Carcass yield & & $73.68 \pm 0.77$ & $71.42 \pm 0.66$ & $72.00 \pm 0.66$ \\
\hline \multirow{3}{*}{ Breast meat } & Breast meat yield & $31.98 \pm 0.67$ & $30.90 \pm 1.27$ & $27.05 \pm 1.28$ \\
& Dry matter & $23.79 \pm 0.77$ & $24.17 \pm 0.47$ & $24.13 \pm 0.44$ \\
& Total nitrogen & $3.23 \pm 0.11$ & $3.37 \pm 0.08$ & $3.35 \pm 0.06$ \\
& Total fat & $1.05 \pm 0.07$ & $1.19 \pm 0.14$ & $1.45 \pm 0.24$ \\
\hline \multirow{3}{*}{ Thigh meat } & Thigh meat yield & $21.74 \pm 0.37$ & $21.78 \pm 0.44$ & $22.76 \pm 0.45$ \\
& Dry matter & $24.61 \pm 0.58$ & $24.24 \pm 0.23$ & $24.99 \pm 0.28$ \\
& Total nitrogen & $2.96 \pm 0.08$ & $2.92 \pm 0.05$ & $2.97 \pm 0.06$ \\
& Total fat & $4.29 \pm 0.44$ & $4.47 \pm 0.40$ & $5.36 \pm 0.44$ \\
\hline
\end{tabular}

Differences between the groups are not significant $(P>0.05)$. TM0 - $0 \%$ mealworms; TM2 - $\%$ mealworms; TM5 - 5\% mealworms.

Table 5. Sensory analysis of breast meat of chickens ( $\mathrm{mm}$ in $100 \mathrm{~mm}$ scale; mean \pm standard error).

\begin{tabular}{|c|c|c|c|c|}
\hline Group & & TM0 & TM2 & TM5 \\
\hline Sensory trait & $\mathrm{n}$ & 60 & 60 & 60 \\
\hline Odour & & $72.62 \pm 1.86$ & $73.65 \pm 2.22$ & $73.18 \pm 2.26$ \\
\hline Colour & & $77.60 \pm 1.57$ & $74.28 \pm 1.71$ & $76.10 \pm 1.82$ \\
\hline Fibriness & & $74.78 \pm 1.89$ & $72.65 \pm 1.96$ & $73.83 \pm 1.90$ \\
\hline Chewiness & & $67.82 \pm 2.27$ & $67.93 \pm 2.03$ & $67.23 \pm 2.35$ \\
\hline Juiciness & & $53.45 \pm 2.76$ & $54.82 \pm 2.84$ & $53.45 \pm 2.70$ \\
\hline Flavour & & $78.37 \pm 1.70^{\mathrm{b}}$ & $70.13 \pm 2.55^{\mathrm{a}}$ & $69.87 \pm 2.10^{\mathrm{a}}$ \\
\hline Fatty taste & & $80.72 \pm 2.59$ & $79.52 \pm 2.88$ & $81.05 \pm 2.43$ \\
\hline
\end{tabular}

a,b - different superscripts in one row mean significant differences $(P<0.05)$. TM0 $-0 \%$ mealworms; TM2 - $2 \%$ mealworms; TM5 - 5\% mealworms. 
Table 6. Sensory analysis of thigh meat of chickens ( $\mathrm{mm}$ in $100 \mathrm{~mm}$ scale; mean \pm standard error).

\begin{tabular}{|c|c|c|c|c|}
\hline Group & & TM0 & TM2 & TM5 \\
\hline Sensory trait & $\mathrm{n}$ & 60 & 60 & 60 \\
\hline$\overline{\text { Odour }}$ & & $75.63 \pm 2.32$ & $76.35 \pm 2.27$ & $77.88 \pm 1.68$ \\
\hline Colour & & $67.37 \pm 2.06$ & $67.10 \pm 2.04$ & $66.02 \pm 2.30$ \\
\hline Fibriness & & $74.72 \pm 1.76$ & $73.55 \pm 1.90$ & $73.07 \pm 1.96$ \\
\hline Chewiness & & $71.03 \pm 2.17$ & $73.25 \pm 1.73$ & $70.53 \pm 1.78$ \\
\hline Juiciness & & $64.07 \pm 2.23$ & $66.60 \pm 1.93$ & $62.87 \pm 2.11$ \\
\hline Flavour & & $72.67 \pm 2.63$ & $70.62 \pm 2.65$ & $74.33 \pm 2.07$ \\
\hline Fatty taste & & $82.00 \pm 2.44$ & $82.33 \pm 2.33$ & $82.37 \pm 2.28$ \\
\hline
\end{tabular}

Differences between the groups are not significant $(P>0.05)$. TM0 - $0 \%$ mealworms; TM2 - $2 \%$ mealworms; TM5 - 5\% mealworms.

\section{Discussion}

In an experiment by Ramos-Elorduy et al. (2002), mealworms grew on low-nutritive waste products and were fed to broiler chickens. The mealworms were able to transform the low nutritive waste products to a high protein diet. Soybean meal (protein content $55 \%$ ) was reduced to $31 \%, 26 \%$, and $20 \%$ of the diet and replaced by $0 \%, 5 \%$, and $10 \%$ of mealworm, respectively. Feed intake, weight gain, and feed efficiency of broilers were evaluated. After 15 days, the results did not show significant differences between the experimental groups. These data indicate that Tenebrio molitor has the potential to be used as a protein source for broiler chickens (Ramos-Elorduy et al. 2002). In contrast to our trial, Bovera et al. (2016) found no significant effect on most growth performance and carcass traits and chemical and physical properties of broilers meat. Similarly to our results, $5 \%, 10 \%$, and $15 \%$ inclusions did not affect carcass traits of Ross 708 broilers (Biasato et al. 2018a).

An earlier study (Bovera et al. 2016) did not find any differences in the chemical composition of the breast meat of Shaver brown broilers fed with $29.65 \%$ Tenebrio molitor larvae in their diet compared to those fed a soybean meal diet. The authors found a $21.4 \%$ breast meat protein content whereas in our study, the protein proportion in the same meat was approximately $20 \%$. The lipid content of $1.45 \%$ in our group TM5 was comparable to the lipid content found by Bovera et al. (2016). Carcass composition of Ross 308 broilers was not influenced by the addition of mealworm meal (at doses of $0 \%, 2 \%, 4 \%, 8 \%$ and $10.48 \%$ ) in diets, indicating that this feed did not worsen the carcass yield characteristics (Elahi et al. 2020). In that study, approximately $23 \%$ breast meat yield for $0 \%, 2 \%$, and $4 \%$ of mealworms in diet was found (Elahi et al. 2020). These carcass quality results are in agreement with other studies (Biasato et al. 2016; Biasato et al. 2018b; Dabbou et al. 2019), where Tenebrio molitor larvae had no effect on carcass quality of broiler and freerange chickens. Several authors (Khatun et al. 2003; Hwangbo et al. 2009; Ballitoc and Sun 2013) found significant differences in carcass yield and reported that the addition of insect meal (house fly-maggots, yellow mealworms, and silkworm pupae) in broiler chicken's diet improved the slaughter weight, carcass yield, breast and thigh muscle yield, and dressing percentage. Bovera et al. (2016) found no effect on the broilers' growth performance, carcass traits, and chemical properties of breast meat. In contrast, other works found a significant difference in the carcass quality of Barbary partridges (Loponte et al. 2017) and Japanese quails (Zadeh et al. 2019) which were fed mealworms in their diet. Otherwise, the quality of breast muscle of Japanese quails was influenced by diets containing black soldier fly (Hermetia illucens), which contained different chemical 
compositions and profiles of amino acids and fatty acids. The physical quality, sensory profile and retail display of the meat remained for the most part unaffected (Wendin et al. 2019).

Although the difference was significant, the reduction in the flavour descriptor was not such as to reduce the overall acceptability or quality of meat for the panellists in our study. Similarly, meat quality characteristics of slow-growing chickens were not affected by the replacement of soybean meal with black soldier fly (7.8\%) in diet (Leiber et al. 2017). The results for meat quality are in agreement with other authors who reported no effect of TM on meat quality (Hussain et al. 2017; Khan et al. 2018; Dabbou et al. 2019). According to Elhassan et al. (2019), the sensory quality of food is one of the main prerequisites for their acceptance by consumers. From this point of view, meat from chickens that had been fed insects could be ingested by consumers without difficulty. After all, poultry bred at home in the backyard eat insects on a regular basis. Insects are (and always have been) a natural component of poultry feed.

From the economic point of view, $2 \%$ of mealworms in the broiler's diet appears to be a suitable option. A similar opinion has been reached by Ballitoc and Sun (2013) who recommended a $2 \%$ inclusion of mealworms to the broiler's diet.

As reported by Madau et al. (2020), several authors have begun to study consumer behaviour regarding foods produced from insect-based foodstuffs. More research is needed to understand the degree of acceptance of insect-based foods and consumer willingness to pay for eating them. These issues are crucial subjects of research, useful for better addressing the choices of insect farmers and the entire supply chain. Edible insects remain underutilized in the animal feed industry (Sogari et al. 2019); however, with the rapid development of intensive industrial insect farming, their potential use is expected to increase. Some researchers in reviews (Madau et al. 2020) reported that the insect protein industry might have to face three main challenges to reach its full potential (Sogari et al. 2019). Firstly, the industry needs to scale up considerably (Makkar et al. 2014; Elahi et al. 2020). Secondly, livestock farmers in the EU must regularly meet the expectations of consumers. They need to inform consumers clearly and intelligibly about safe, nutritious, and high-quality products of animal origin (Madau et al. 2020). Third, basic principles in General Food Law will have to be strictly followed by insect producers, and this should be supported by research to determine whether such procedure might affect the quality of the final food for consumers (Bovera et al. 2016; Cullere et al. 2019; Wendin et al. 2019). Some insect species may grow on organic side-streams, thus reducing environmental contamination and converting waste into high protein feed which could replace current, increasingly more expensive compound feed ingredients, such as fish meal. This requires the development of cost-effective, automated mass-rearing facilities that provide a reliable, stable, and safe product. In the Western world, consumer acceptability will relate to pricing and perceived environmental benefits (van Huis 2013).

Economic arguments for adding mealworms to the broiler chicken diet must be found outside the simple focus on productivity efficiency. Compared to the traditional sources of protein in broiler chicken diets, the price of dried mealworms is significantly higher. However, the higher price can be explained and justified to customers by marketing arguments stressing the benefits of decreased pressure on the environment and of replacement of the currently used protein sources, such as fish powder, by a natural one, namely insects. There is already an important part of consumer segments who are willing to pay a higher price if the aspect of sustainability of the production is part of the product's story.

In conclusion, the proportion of yellow mealworms at the doses of $2 \%$ and $5 \%$ in broiler chickens feed mixture did not worsen the chemical composition and sensory characteristic of the thigh meat of broilers, reflecting optimal sensory quality traits. The breast meat 
from the control group was rated better in the flavour descriptor compared to the groups receiving $2 \%$ and $5 \%$ of yellow mealworms. There was a tendency to perceive a worse breast meat flavour, but no significant reduction in the overall meat quality was found. Our results show that the inclusion of $2 \%$ and $5 \%$ mealworm meal in the broiler's diet did not markedly affect the meat quality. The inclusion of mealworms in the broilers diet is possible, however, it is important to bear in mind that under certain conditions, it can affect the chickens' growth and meat quality, and attention must be paid to the feed quality. More studies on the subject are needed in order to determine a recommendation for the suitable amount of mealworm meal in the broiler's diet.

\section{Acknowledgments}

This study was supported by the grant TJ02000018 "The use of mealworms in animal nutrition" of the Technology Agency of the Czech Republic.

\section{References}

Aviagen Group 2018: Technological procedure for broiler Ross. Available at: http://eu.aviagen.com/languagemini-site/show/cz. Last modified July 24, 2019. Accessed November 16, 2020

Aviagen Group 2019: Broiler nutrition specifications. Available at: http://eu.aviagen.com/language-mini-site/ show/cz. Last modified May 23, 2019. Accessed November 16, 2020

Ballitoc DA and Sun S 2013: Ground yellow mealworms (Tenebrio molitor L.) feed supplementation improves growth performance and carcass yield characteristics in broilers. Open Science Repository Agriculture, e23050425. https://doi.org/10.7392/openacces.2305042

Biasato I, De Marco M, Rotolo L, Renna M, Lussiana C, Dabbou S, Capucchio MT, Biasibetti E, Costa P, Gai F, Pozzo L, Bergagna S, Martínez S, Tarantola M, Gasco L, Schiavone A 2016: Effects of dietary Tenebrio molitor meal inclusion in free-range chickens. J Anim Physiol Anim Nutr 100: 1104-1112

Biasato I, Ferrocino I, Biasibetti E, Grego E, Dabbou S, Sereno A, Gai F, Gasco L, Schiavone A, Cocolin L 2018b: Modulation of intestinal microbiota, morphology and mucin composition by dietary insect meal inclusion in free-range chickens. BMC Vet Res 14: 383

Biasato I, Gasco L, De Marco M, Renna M, Rotolo L, Dabbou S, Capucchio MT, Biasibetti E, Tarantola M, Sterpone L, Cavallarin L, Gai F, Pozzo L, Bergagna S, Dezzutto D, Zoccarato I, Schiavone A 2018a: Yellow mealworm larvae (Tenebrio molitor) inclusion in diets for male broiler chickens: Effects on growth performance, gut morphology, and histological findings. Poult Sci 97: 540-548

Bovera F, Loponte R, Marono S, Piccolo G, Parisi G, Iaconisi V, Gasco L, Nizza A 2016: Use of Tenebrio molitor larvae meal as protein source in broiler diet: Effect on growth performance, nutrient digestibility, and carcass and meat traits. J Anim Sci 94: 639-647

Collavo A, Glew RH, Huang YS, Chuang LT, Bosse R, Paoletti M 2005: House cricket smallscale farming. In: Ecological Implications of Minilivestock: Potential of Insects, Rodents, Frogs and Snails. Science Publishers, Inc., New Hampshire, pp. 519-544

Commission regulation (EC) 1069/2009. Laying down health rules as regards animal by-products and derived products not intended for human consumption Brussels: The commission of the European Communities

Commission regulation (EC) 152/2009. Laying down the methods of sampling and analysis for the official control of feed. Brussels: The commission of the European Communities

Cullere M, Woods MJ, van Emmenes L, Pieterse E, Hoffman LC, Dalle Zotte A 2019: Hermetia illucens larvae reared on different substrates in broiler quail diets: effect on physicochemical and sensory quality of the quail meat. Animals 9: 525

Dabbou S, Gasco L, Lussiana C, Brugiapaglia A, Biasato I, Renna M, Cavallarin L, Gai F, Schiavone A 2019: Yellow mealworm (Tenebrio molitor L.) larvae inclusion in diets for free-range chickens: Effects on meat quality and fatty acid profile. Renew Agric Food Syst 1-8

Elahi U, Wang J, Ma YB, Wu SG, Wu J, Qi GH, Zhang HJ 2020: Evaluation of yellow mealworm meal as a protein feedstuff in the diet of broiler chicks. Animals 10: 224

Elhassan M, Wendin K, Olsson V, Langton M 2019. Review paper: The appeal of insects as human food-with emphasis on mealworm texture, taste, and flavor. Foods 8: 95

Gasco L, Acuti G, Bani P, Dalle Zotte A, Danieli PP, De Angelis A, Fortina R, Marino R, Parisi, G, Piccolo G, Pinotti L, Prandini A, Schiavone A, Terova G, Tulli F, Roncarati A 2020: Insect and fish by-products as sustainable alternatives to conventional animal proteins in animal nutrition. Ital J Anim Sci 19: 360-372

Ghaly AE, Alkoaik FN 2009: The yellow mealworm as a novel source of protein. Am J Agric Biol Sci 4: $319-331$

Hoffman LC, Claasen B, Van der Merwe DA, Cloete SWP, Cloete JJE, 2020: The effects of production system and sex on the sensory quality characteristics of dorper lamb. Foods 9: 725

Hussain I, Khan S, Sultan A, Chand N, Khan R, Alam W, Ahmad N 2017: Meal worm (Tenebrio molitor) as potential alternative source of protein supplementation in broiler. Int J Biosci 10: 255-262 
Hwangbo J, Hong EC, Jang A, Kang HK, Oh JS, Kim BW, Park BS 2009: Utilization of house fly-maggots, a feed supplement in the production of broiler chickens. J Environ Biol 30: 609-614

ISO 8586. Sensory Analysis-General Guidelines for the Selection, Training and Monitoring of Selected Assessors and Expert Sensory Assessors. International Organization for Standardization: Geneva, Switzerland, 2012

ISO 8589. Sensory Analysis-General Guidance for the Design of Test Rooms. International Organization for Standardization: Geneva, Switzerland, 2012

Khan S, Khan RU, Alam W, Sultan A 2018: Evaluating the nutritive profile of three insect meals and their effects to replace soya bean in broiler diet. J Anim Physiol Anim Nutr 102: 662-668

Khatun R, Howlider MAR, Rahman MM, Hasanuzzaman M 2003: Replacement of fish meal by silkworm pupae in broiler diets. Pak J Biol Sci 6: 955-958

Leiber F, Gelencsér T, Stamer A, Amsler Z, Wohlfahrt J, Früh B, Maurer V 2017: Insect and legume-based protein sources to replace soybean cake in an organic broiler diet: effects on growth performance and physical meat quality. Renew Agric Food Syst 32: 21-27

Loponte R, Nizza S, Bovera F, De Riu N, Fliegerova K, Lombardi P, Vassalotti G, Mastellone V, Nizza A, Moniello G 2017: Growth performance, blood profiles and carcass traits of Barbary partridge (Alectoris barbara) fed two different insect larvae meals (Tenebrio molitor and Hermetia illucens). Res Vet Sci 115: 183-188

Madau FA, Arru B, Furesi R, Pulina P 2020: Insect farming for feed and food production from a circular business model perspective. Sustainability 12: 5418

Makkar HPS, Tran G, Heuze V, Ankers P 2014: State-of-the-art on use of insects as animal feed. Anim Feed Sci Technol 197: 1-33

Ramos-Elorduy J, Avila Gonzalez E, Rocha Hernandez A, Pino JM 2002: Use of Tenebrio molitor (Coleoptera: Tenebrionidae) to recycle organic wastes and as feed for broiler chickens. J Econ Entomol 95: 214-220

Sogari G, Amato M, Biasato I, Chiesa S, Gasco L 2019: The potential role of insects as feed: a multi-perspective review. Animals 9: 119

van Huis A 2013: Potential of insects as food and feed in assuring food security. Annu Rev Entomol 58: 563-583

Vogt H 1984: The new WPSA (World Poultry Science Association) formula for estimating the content of metabolizable energy in poultry diets. Kraftfutter

Wendin K, Olsson V, Langton M 2019: Mealworms as food ingredient-Sensory investigation of a model system. Foods 8: 319

Zadeh ZS, Kheiri F, Faghani M 2019: Use of yellow mealworm (Tenebrio molitor) as a protein source on growth performance, carcass traits, meat quality and intestinal morphology of Japanese quails (Coturnix japonica). Veter Anim Sci 8: 100066 